\title{
PENGARUH KINERJA KEUANGAN TERHADAP PROFITABILITAS BANK BTN SEBELUM DAN SESUDAH SEKURITISASI ASET
}

\author{
Gos Ishak')
}

1) dosen Universitas Pamulang, email :gos ishak@yahoo.com

\section{ARTICLES}

INFORMATION

\section{ABSTRACT}

\section{JURNAL SEKURITAS \\ (Saham, Ekonomi, Keuangan dan Investasi ) \\ Vol.1, No.4, Juni 2018 \\ Halaman : $80-91$ \\ (c) LPPM \& Prodi Manajemen \\ UNIVERSITAS PAMULANG \\ ISSN (online) : 2581-2777 \\ ISSN (print) : :2581-2696}

\section{Keyword :}

Sekuritisasi Aset, KIK EBASP, KPR Bersubsidi, Bank, Backlog, PNS, Pembiayaan Perumahan, APBN, Pasar Modal.

JEL. classification : C33, G20, G23, N65

\section{Contact Author :}

PRODI MANAJEMEN UNPAM

JL.Surya Kencana No.1 Pamulang

Tangerang Selatan - Banten

Telp. (021) 7412566, Fax (021) 7412491 Email :

jurnalfinance.unpam@gmail.com
Rumah layak huni dan terjangkau bagi PNS (Pegawai Negeri Sipil/ASN) dan masyarakat berpenghasilan rendah (MBR) merupakan permasalahan yang hingga kini belum dapat diatasi secara tuntas. Meskipun berbagai program telah digulirkan pemerintah untuk menyelesaikannya namun jumlah backlog perumahan semakin bertambah (kebutuhan saat ini mencapai 13,5 juta unit, sedangkan pembangunan rumah baru hanya sekitar 300-400 ribu unit per tahun)(Sumber Bappenas \& BPS Tahun 2015). Adapun kendala pembiayaan pemerintah melalui APBN sangat terbatas, alokasi anggaran perumahan FLPP (Fasilitas Likuiditas Pembiayaan Perumahan) yaitu Rp $9 \mathrm{~T}$ di tahun 2015 atau hanya sekitar $0.375 \%$ dari APBN $2400 \mathrm{~T}$ (atau kurang dari $1 / 2 \%$ ). Untuk itu, Bank BTN ditunjuk sebagai Bank Penyalur program kredit perumahan rakyat (KPR-Bersubsidi FLPP) oleh Pemerintah, hasil kinerja keuangan Bank BTN sebelum dan sesudah sekuritisasi asset akan dikaji lebih lanjut, sekaligus dapat memberikan masukan kepada seluruh stakeholders agar solusi backlog dan pembiayaan perumahan dapat memberi kontribusi mengatasi permasalahan perumahan.

Habitable and affordable housing for civil servants (PNS / $A S N)$ and low-income people (MBR) is a problem that until now can not be solved completely. Although various programs have been initiated by the government to resolve them, the number of housing backlogs has grown (the current needs reach 13.5 million units, while the construction of new houses is only about 300-400 thousand units per year) (Source Bappenas \& BPS Year 2015). The government funding constraint through APBN is very limited, the allocation of housing budget of FLPP (Housing Financing Liquidity Facility) is Rp $9 T$ in 2015 or only about $0.375 \%$ of State Budget 2400 T (or less than $1 / 2 \%$ ). To that end, Bank BTN is appointed as a Distribution Bank of the community housing loan program (KPR-Subsidized FLPP) by the Government, the results of Bank BTN's financial performance before and after asset securitization will be reviewed further, as well as to provide input to all stakeholders for backlog and housing finance solutions can contribute to resolve housing problems. 


\section{A. Pendahuluan}

Program pembangunan sejuta rumah telah dicanangkan oleh Presiden Joko Widodo pada tanggal 29 April 2015, telah bergulir dan terbukti menjadi penopang industri property untuk segmen bawah. Pemerintah sendiri mengklaim telah berhasil merealisasikan sekitar 60 persen dari target pembangunan sejuta rumah pada 2015 lalu. Masih cukup banyak kendala yang harus dihadapi dalam pelaksanaan program sejuta rumah dengan kendala terbesar di seputar kesiapan lahan untuk dibangun rumah murah, selain belum singkronnya peraturan antara pemerintah pusat dan daerah. Namun, dengan pengalaman program yang sudah dilalui tahun lalu, pemerintah merasa optimis untuk bisa mewujudkan program sejuta rumah yang lebih baik pada tahun 2016 .

Pertanyaan yang muncul berapa rumah yang telah disalurkan di tahun 2015 dalam program sejuta rumah. Menurut Dirjen Penyediaan Perumahan Kementerian Pekerjaan Umum dan Perumahan Rakyat (PUPR), program sejuta rumah yang berhasil diwujudkan sepanjang 2015 mencapai 667.668 unit. Adapun strategi pemerintah untuk mendorong program tersebut adalah mendorong kalangan pengembang mulai yang kecil hingga besar untuk terus memperbanyak pembangunan rumah murah terlebih lagi yang rumah tapak (vertical) atau rumah susun (rusun). Pemerintah juga telah mengeluarkan PP (Peraturan Pemerintah) untuk mengembalikan peran Perumnas menjadi penyedia utama rumah rakyat bahkan dengan fungsi dan wewenang yang lebih misalnya sebagai penjamin proyek yang macet, penyedia landbank, dan sebagainya. Dukungan lainnya akan diberikan pemerintah melalui regulasi dan sinkronisasi dengan pemerintah daerah selain menggelontorkan anggaran yang lebih besar mencapai lebih dari Rp $13 \mathrm{~T}$ dibandingkan 2015 yang hanya sekitar Rp 5,6 T. Proporsi pembangunan sejuta rumah tahun ini ditingkatkan menjadi 700 ribu unit rumah untuk kalangan Masyarakat Berpenghasilan Rendah (MBR) dan 300 ribu unit rumah untuk kalangan non MBR (total 1 juta unit rumah). Untuk itu melalui peran yang diemban Bank BTN sebagai penyalur kredit perumahan rakyat (KPR Bersubsidi-FLPP) melalui program sejuta rumah pemerintah yang ditunjuk oleh Pemerintah dapat memberikan kontribusi mengatasi backlog dan pembiayaan perumahan.

\section{A.1 Issue Strategis}

a. Bagaimana kinerja Bank BTN sebelum dan sesudah sekuritisasi.

b. Backlog perumahan menurut data BPS dan Bappenas sebesar 13.5 juta unit.

c. Banyaknya regulasi perijinan yang harus dipenuhi oleh pengembang.

d. Lokasi perumahan yang kurang strategis disamping harga tanah yang mahal.

e. Peraturan daerah yang belum sejalan dengan peraturan diterbitkan oleh pemerintah pusat.

f. Harga rumah yang semakin mahal rata rata kenaikan $5 \%$ untuk rumah subsidi dan non subsidi $20 \%$ tergantung lokasinya.

g. Tingkat laju pertambahan penduduk rata rata pertahun $1,49 \%$.

h. Terbatasnya anggaran APBN.

\section{A.2 Rumusan Masalah}

Untuk mengatasi masalah pembiayaan perumahan bagi masyarakat berpenghasilan rendah (MBR) dan golongan PNS (Pegawai Negeri Sipil) yang mempunyai penghasilan gaji pokok maksimal Rp 4 juta, maka melalui makalah tersebut penulis mencoba membahas tentang pembiayaan perumahan untuk MBR dan PNS, adalah sebagai berikut:

a. EBA (efek beragun asset) adalah salah satu varian hutang merupakan proses mengubah bentuk piutang yang dalam hal ini adalah tagihan tagihan dalam bentuk instrument efek yang dapat memberikan likuiditas. 
b. EBA merupakan suatu proses mentransformasi atau mengubah sesuatu yang bukan efek menjadi efek yang bersifat likuid sehingga mudah diperdagangkan.

c. Sekuritisasi asset merupakan suatu proses mencari dana (raising fund) melalui pengisian sekuritas (efek) yang di backup oleh arus keuangan (cash flow) dimasa depan yang berasal dari pool terhadap asset yang menghasilkan revenue ke dalam sekuritas (efek) yang dapat diperdagangkan.

\section{B. Tujuan Penelitian}

Adapun maksud dan tujuan dari makalah ini adalah untuk mengkaji kinerja Bank BTN sebelum dan sesudah sekuritisasi aset dan sekaligus memberikan masukan kepada para pembaca/stakeholders/pengambil keputusan dibidang perumahan bagaimana mengatasi masalah pembiayaan perumahan khususnya untuk golongan MBR dan PNS yang berpenghasilan kurang dari Rp 4 juta rupiah. Sebagaimana kita ketahui bersama bahwa kekurangan pasokan perumahan (backlog) saat ini telah mencapai 13.5 juta unit (Sumber: Bappenas \& BPS tahun 2015) rumah apabila dikalikan dengan harga rumah bersubsidi nasional (type luas bangunan 36 luas tanah 72) Rp 120-150 juta (Daftar harga yang dikeluarkan oleh Kementerian Keuangan untuk periode 2014-2018) dibutuhkan dana Rp 1820 Triliun. Suatu jumlah yang sangat besar dan Pemerintah mempunyai keterbatasan dalam membiayai melalui APBN dan apabila tidak segera diatasi hal tersebut bisa menjadi masalah nasional.

\section{Hipotesis}

\section{1. Pengembangan Hipotesis}

\section{H1a: Apakah CAR (Capital Adequacy Ratio) berpengaruh terhadap profitabilitas bank (ROA).}

Asumsi umum didunia perbankan semakin tinggi rasio CAR bank semakin rendah kemungkinan dari biaya financial distress dan benefit, hal tersebut dapat mendongkrak laba bank (Abreu and Mendes, 2002; Ben Naceur, 2003). Khususnya, Abreu dan Mendes membuktikan bahwa beberapa Negara di Eropah, yang mempunyai modal Bank yang kuat (CAR) diprediksi lebih kecil dari kebangkrutan, dan rendahnya biaya pendanaan dan interest margin tinggi dalam mencetak laba. Equity yang kuat (besar) akan mengurangi cost of capital menyebabkan dampak positif dalam mencetak laba. Ditambahkan, bank dengan rasio profitability (ROA-ROE) mengurangi kebutuhan external funding bank.

H1a: Diduga CAR mempunyai hubungan yang positif dengan profitabilitas bank (ROA) pada sekuritisasi aset.

\section{H1b: Apakah NPL (Non Performing Loan) berpengaruh terhadap profitabilitas bank (ROA).}

Rasio provisi kredit macet terhadap total loans adalah untuk mengukur pengaruh asset kualitas bank dalam mencetak laba. Rasio provisi kredit macet dibandingkan apakah total pinjaman (misalnya asset quality ratio) satu kesatuan yang berdiri sendiri karena rasio yang tinggi dapat membuat kualitas pinjaman berdampak ke risiko pinjaman portofolio. Rasio yang tinggi (bad debts) mengindikasikan penurunan kualitas kredit, sehingga menyebabkan mengurangi laba.

Menurut Fu dan Heffernan (2010), mengindikasikan hubungan rasio tsb. Dengan profitabilitas dapat negative disebabkan besarnya indikasi provisi yang menilai 
kemungkinan kredit macet dikemudian hari. Oleh sebab itu sulit di antisipasi hubungan antara ratio kualitas asset dan profitabilitas, tetapi hasilnya majoritas dari penelitian sebelumnya menyimpulkan sbb:

H1b: Diduga NPL mempunyai hubungan negative terhadap profitabilitas bank (ROA) pada sekuritisasi aset.

H1c: Apakah NIM (Net Interest Margin) berpengaruh terhadap profitabilitas Bank (ROA).

NIM adalah net interest margin dibagi dengan total asset. NIM adalah perbedaan antara interest income yang dihasilkan oleh bank (income from loans dan securities) dan sejumlah bunga yang wajib dibayarkan bank kepada deposan dan creditors kepada siapa bank meminjam dibagi rata rata jumlah pendapatan bunga dari asset bank (termasuk loans, investments dan fixed income securities). NIM dipakai untuk mengukur kinerja karena dapat mengukur hasil keuntungan bank dari pendapatan bunga bank.

H1c: Diduga NIM mempunyai hubungan positif terhadap profitabilitas bank (ROA) pada sekuritisasi aset.

H1d: Apakah LDR (Loan Deposit Ratio) berpengaruh terhadap profitabilitas Bank (ROA).

Menurut penelitian sebelumnya, total loans to total asset ratio (loan ratio) sebagai indicator liquiditas dan mempunyai hubungan yang positif antara likuiditas dan profitabilitas. (Bashir 2003;Sufian and Habibullah, 2009). Likuiditas adalah sangat penting bagi keuntungan bank dan pinjaman (loans) adalah sumber utama pendapatan dan diestimasi mempunyai dampak positif dalam kinerja bank. Dltambahkan, jika bank meningkatkan volume pinjaman dengan margin yang rendah, kemungkinan berdampak negative terhadap laba. Disebabkan dampak loan ratio keuntungan beralih kearah yang berlawanan, sehingga hasil keuntungan bank tidak dapat diprediksi secara teori.

Dapat disimpulkan ukuran pinjaman kredit dari bank akan mempengaruhi profitabilitas kejalan positif atau negative, tergantung komposisi credit quality.

H1d: Diduga LDR (Loan Deposit Ratio) mempunyai hubungan positif terhadap profitabilitas bank (ROA) pada sekuritisasi aset.

Tabel 1: Pengukuran Variable dan Identifikasi

\begin{tabular}{|l|l|l|}
\hline Variable & Definisi & Keterangan \\
\hline Dependent Variable & & $\begin{array}{l}\text { Kemampuan mendapatkan } \\
\text { keuntungan dari asset bank } \\
\text { dan mengindikasikan } \\
\text { seberapa efektif sumber } \\
\text { bank mendapatkan } \\
\text { keuntungan. }\end{array}$ \\
\hline $\begin{array}{l}\text { Independent Variable } \\
\text { Ratio) (Capital Adequacy }\end{array}$ & Eet Profit/Total Asset & $\begin{array}{l}\text { Untuk menghitung CAR } \\
\text { yaitu pinjaman yang } \\
\text { diberikan (rata-rata } \\
\text { tertimbang) dibagi dengan } \\
\text { total asset. Semakin tinggi }\end{array}$ \\
\hline
\end{tabular}




\begin{tabular}{|l|l|l|}
\hline & & $\begin{array}{l}\text { rasio CAR bank semakin } \\
\text { rendah kemungkinan dari } \\
\text { biaya financial distress dan } \\
\text { benefit in dapat } \\
\text { mendongkrak laba bank. }\end{array}$ \\
\hline $\begin{array}{l}\text { NPL (Non Performing } \\
\text { Loan) }\end{array}$ & Loan Provisions/Loans & $\begin{array}{l}\text { Untuk mengukur pengaruh } \\
\text { asset kualitas bank dalam } \\
\text { mencetak laba. Ratio yang } \\
\text { tinggi (bad debts) } \\
\text { mengindikasikan } \\
\text { penurunan kualitas kredit } \\
\text { sehingga berdampak } \\
\text { penurunan laba. }\end{array}$ \\
\hline NIM (Net Interest Margin) & $\begin{array}{l}\text { Net Interest Income/Total } \\
\text { Asset }\end{array}$ & $\begin{array}{l}\text { NIM dipakai untuk } \\
\text { mengukur kinerja karena } \\
\text { dapat mengukur hasil } \\
\text { keuntungan bank dari } \\
\text { pendapatan bunga bank. }\end{array}$ \\
\hline $\begin{array}{l}\text { LDR (Loan to Deposit } \\
\text { Ratio) }\end{array}$ & Total Loans/Total Asset & $\begin{array}{l}\text { Sebagai indikator liquiditas } \\
\text { dan mempunyai hubungan }\end{array}$ \\
& & $\begin{array}{l}\text { yang positif antara likuiditas } \\
\text { dan probabilitas. Likuiditas } \\
\text { adalah sangat penting bagi } \\
\text { keuntungan bank dan } \\
\text { pinjaman merupakan } \\
\text { sumber utama pendapatan } \\
\text { dan diperkirakan } \\
\text { mempunyai dampak positif } \\
\text { dalam kinerja bank. }\end{array}$ \\
& &
\end{tabular}

\section{Metodologi}

\section{D.2 Data dan Sampel}

Sampel terdiri 118 Bank (Bank Devisa dan Non Devisa) dari tahun 2006 - 2016 (Nov), dengan total asset Rp $6581 \mathrm{~T}$, Kredit yang disalurkan Rp $4314 \mathrm{~T}$, DPK $4733 \mathrm{~T}$, Laba Bersih $104 \mathrm{~T}$. Dari data tersebut, akan dikaji kinerja Bank BTN yaitu CAR, NPL, NIM dan LDR (Independent Variable) dan ROA (Dependent Variable) sebelum dan sesudah sekuritisasi asset bank BTN.

Adapun variabel yang dianggap mengukur kinerja perusahaan dalam metodologi ini adalah : ROA (Dependent Variabel)

Sedangkan CAR, NPL, NIM dan LDR. (Independent Variabel)

Untuk menghitung profitabilitas akan memakai regression model, sebagai berikut:

$R O A=\alpha o+\beta 1 C A R+\beta 2 N P L+\beta 3 N I M+\beta 4 L D R+\beta 5$ Dummy

Berikut pengolahan data dengan memakai program eviews 9: 


\section{E. Hasil dan Pembahasan}

\section{a. Statistic Deskriptif}

$\begin{array}{lccccc} & \text { ROA } & \text { CAR } & \text { NPL } & \text { LDR } & \text { NIM } \\ \text { Mean } & 1.723750 & 17.32125 & 2.622500 & 103.7888 & 5.222500 \\ \text { Median } & 1.775000 & 16.85500 & 2.755000 & 102.5800 & 5.210000 \\ \text { Maximum } & 2.050000 & 21.54000 & 3.120000 & 108.8600 & 5.830000 \\ \text { Minimum } & 1.140000 & 14.64000 & 1.850000 & 100.9000 & 4.470000 \\ \text { Std. Dev. } & 0.309559 & 2.473895 & 0.495400 & 3.314408 & 0.562031 \\ \text { Skewness } & -0.735347 & 0.667508 & -0.417481 & 0.786989 & -0.095840 \\ \text { Kurtosis } & 2.538330 & 2.125256 & 1.632778 & 1.981788 & 1.387249 \\ & & & & & \\ \text { Jarque-Bera } & 0.792027 & 0.849148 & 0.855486 & 1.171387 & 0.879235 \\ \text { Probability } & 0.672998 & 0.654048 & 0.651979 & 0.556720 & 0.644283 \\ & & & & & \\ \text { Sum } & 13.79000 & 138.5700 & 20.98000 & 830.3100 & 41.78000 \\ \text { Sum Sq. Dev. } & 0.670787 & 42.84109 & 1.717950 & 76.89709 & 2.211150 \\ & & & & & \\ \text { Observations } & 8 & 8 & 8 & 8 & 8\end{array}$

Untuk ROA nilai tertinggi maximum 2.05 (<industry 2.78) yang terjadi di tahun 2010. Sedangkan CAR 21.54 (>Industri 18.78) yang terjadi di tahun 2009 , NPL 3.12 (>Industri 2.26) yang terjadi di tahun 2010, LDR 108 (> 84.05) yang terjadi di tahun 2015 dan NIM 5.83(>5.35) yang terjadi di tahun 2010 . Bank BTN adalah Bank yang mengemban misi Pemerintah dalam menyalurkan kredit perumahan sehingga produk kreditnya memang tidak variatif dan tidak sebagus dengan produk bank-konvensional yang menyalurkan kredit konsumtif. Bank BTN sudah mulai melakukan sekuritisasi asset sejak tahun 2009 , dimana kredit utamanya yaitu kredit KPR dimana jangka waktunya 1520 tahun. Untuk mengoptimalkan pendanaan, Bank BTN melalui sekuritisasi asset melakukan penjualan asset KPR (asset yang kualitasnya bagus) ke Investor yang selanjutnya dana disalurkan kembali ke kredit KPR, hal tersebut dapat meringankan pendanaan perumahan yang bersumber dari APBN.

\section{b. Uji Normalitas}

Ho: Data berdistribusi Normal

Ha: Data berdistribusi Tidak Normal

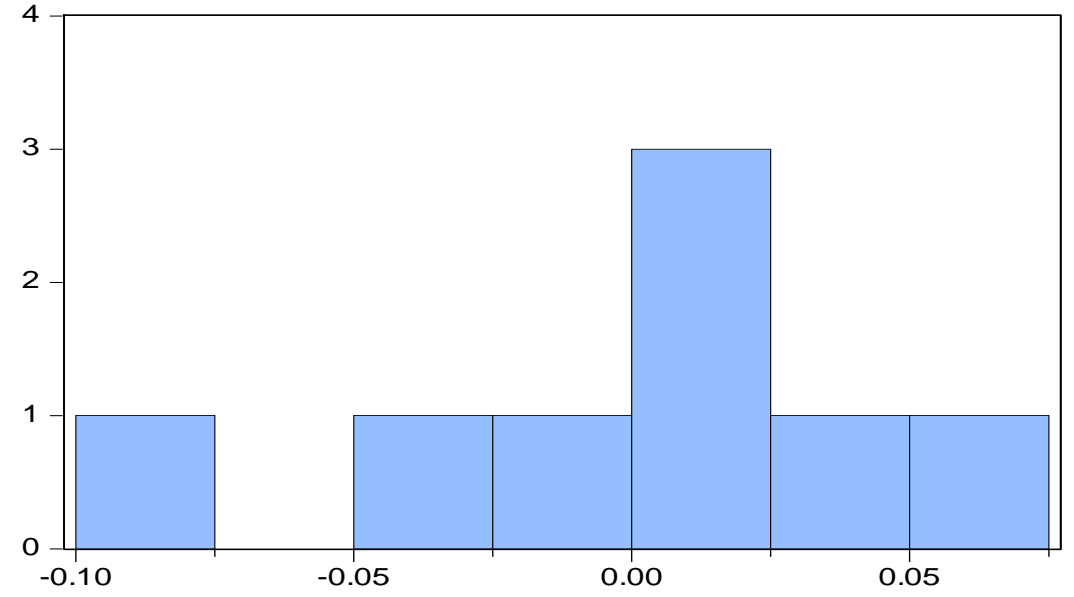

Series: Residuals

Sample 20092016

Observations 8

Mean

3.33e-16

Median

0.010510

Maximum

0.053617

Minimum

$-0.087310$

Std. Dev.

0.046035

Skewness $\quad-0.731224$

Kurtosis

2.621289

Jarque-Bera

0.760726

Probability

0.683613 
Prob. Jarque-Bera : $0.683613>\alpha=5 \%$

Ho diterima

Data berdistribusi Normal

\section{Regresi Awal}

Dependent Variable: ROA

Method: Least Squares

Date: 02/21/18 Time: 17:29

Sample: 20092016

Included observations: 8

\begin{tabular}{rrrrr}
\hline \hline \multicolumn{1}{c}{ Variable } & Coefficient & Std. Error & t-Statistic & Prob. \\
\hline CAR & 0.032554 & 0.023911 & 1.361484 & 0.2666 \\
NPL & -0.139666 & 0.064349 & -2.170443 & 0.1184 \\
LDR & 0.004618 & 0.021216 & 0.217674 & 0.8416 \\
NIM & 0.616263 & 0.107689 & 5.722631 & 0.0106 \\
C & -2.171600 & 3.157158 & -0.687834 & 0.5410 \\
\hline \hline R-squared & 0.977885 & Mean dependent var & 1.723750 \\
Adjusted R-squared & 0.948398 & S.D. dependent var & 0.309559 \\
S.E. of regression & 0.070319 & Akaike info criterion & -2.202365 \\
Sum squared resid & 0.014834 & Schwarz criterion & -2.152714 \\
Log likelihood & 13.80946 & Hannan-Quinn criter. & -2.537241 \\
F-statistic & 33.16359 & Durbin-Watson stat & 2.660124 \\
Prob(F-statistic) & 0.008113 & & & \\
\hline \hline
\end{tabular}

c. Uji Asumsi Klasik

1. Uji Autokorelasi

Ho: Tidak ada korelasi antara galat $t$ dengan $t-1$

$\mathrm{Ha}$ : Ada korelasi antara galat t dengan t-1

Breusch-Godfrey Serial Correlation LM Test:

\begin{tabular}{llll}
\hline \hline F-statistic & 0.662484 & Prob. F(1,2) & 0.5012 \\
Obs ${ }^{*}$-squared & 1.990573 & Prob. Chi-Square(1) & 0.1583 \\
\hline
\end{tabular}

Prob. Chi-Square (1) dari Obs ${ }^{*} \mathrm{R}$-squared $=0.1583>\alpha=5 \%$

Ho diterima

Tidak ada korelasi antara galat $\mathbf{t}$ dengan $\mathbf{t}-\mathbf{1}$

2. Uji Heteroskedastisitas

Ho: Varians konstan

Ha: Varians tidak konstan

Heteroskedasticity Test: Glejser

\begin{tabular}{llll}
\hline \hline F-statistic & 2.695313 & Prob. F(4,3) & 0.2208 \\
Obs*R-squared & 6.258504 & Prob. Chi-Square(4) & 0.1807 \\
Scaled explained SS & 2.221733 & Prob. Chi-Square(4) & 0.6951 \\
\hline \hline
\end{tabular}


Prob. Chi-Square (4) dari Obs ${ }^{\star} R$-squared $=0.1807>\alpha=5 \%$

Ho diterima

Varians konstan

\section{Uji Multikolinieritas}

$\begin{array}{lcccc} & \text { CAR } & \text { NPL } & \text { LDR } & \text { NIM } \\ \text { CAR } & 1.000000 & -0.221405 & -0.467044 & -0.302833 \\ \text { NPL } & -0.221405 & 1.000000 & -0.296882 & 0.343482 \\ \text { LDR } & -0.467044 & -0.296882 & 1.000000 & -0.599066 \\ \text { NIM } & -0.302833 & 0.343482 & -0.599066 & 1.000000\end{array}$

Dari table diatas terlihat bahwa korelasi antar independen variabel dibawah / lebih kecil dari 0.8. Artinya, tidak terdapat korelasi yang kuat antar independen variable.

\section{Persamaan Regresi:}

Estimation Command:

LS ROA CAR NPL LDR NIM C

Estimation Equation:

$\mathrm{ROA}=\mathrm{C}(1)^{\star} \mathrm{CAR}+\mathrm{C}(2)^{\star} \mathrm{NPL}+\mathrm{C}(3)^{\star} \mathrm{LDR}+\mathrm{C}(4)^{\star} \mathrm{NIM}+\mathrm{C}(5)$

Substituted Coefficients:

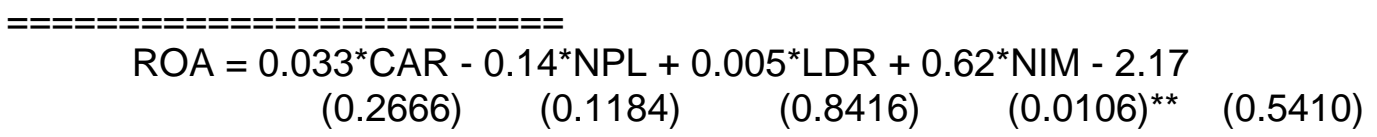

\section{*significance at $1 \%$ \\ ** significance at $5 \%$ \\ ${ }^{\star * *}$ significance at $10 \%$}

\section{d. Interpretasi}

Dari hasil diatas, diketahui bahwa nilai prob. t-statistic CAR, NPL dan LDR tidak signifikan atau lebih besar dari alpha $(\alpha)$, menunjukkan bahwa variabel-variabel tersebut tidak berpengaruh terhadap dependen variabel (ROA).

Satu-satunya variabel yang mempengaruhi ROA adalah NIM, dengan nilai prob. t-statistic lebih kecil dari alpha $(\alpha=5 \%)$

Merujuk penelitian sebelumnya oleh Alp et al. (2010), Smirlock (1985), Boyd and Runkle (1993), Clarke et al. (1984) yang melakukan penelitian hubungan size dan profitabilitas, bahwa size dapat memaksimalkan profitabilitas. Bank BTN diantara bank pemerintah, bank BTN adalah yang memiliki asset yang terkecil. Adapun dampaknya kepada CAR, NPL dan LDR tidak berpengaruh terhadap ROA, hal tersebut disebabkan diantaranya masalah size, jika ukuran size lebih besar, maka market share yang dimiliki juga lebih besar dan dapat mengurangi risiko dalam skala ekonomi, sehingga dapat meningkatkan efisiensi dalam operasional bank, dalam hal efisiensi bank, bank yang sizenya besar jauh 
lebih efisien yang otomatis dapat meningkatkan NIM, ROA dan CAR dan menurunkan NPLdanLDR.

\section{e. Studi Empiris}

Berbagai studi empiris telah dilakukan baik oleh akademisi, peneliti maupaun praktisi mengenai sekuritisasi. Dari beberapa studi yang pernah dilakukan, umumnya melihat manfaat dan tujuan dari sekuritisasi asset serta hal-hal yang menjadi potensi kendala dalam implementasi sekuritisasi asset sebagaimana dimuat dalam Tabel berikut ini (Sumber: Pemanfaatan Sekuritisasi Aset Dalam Mendorong Sektor Riil: Alternatif Pembiayaan UMKM, Wijoyo Santoso, Shinta R.I Soekro, Darmansyah, Hilde D. Sihaloho).

\section{Tabel 2: Penelitian Terdahulu Mengenai Sekuritisasi Aset}

\begin{tabular}{|c|c|c|}
\hline No. & Sumber & Kesimpulan Hasil Penelitian \\
\hline 1. & $\begin{array}{l}\text { Isnawangsih, Agnes } \\
(1998 / 99) \\
\text { Sekuritisasi Aset di } \\
\text { Indonesia }\end{array}$ & $\begin{array}{l}\text { - Dengan mensubstitusikan asetnya bank dapat } \\
\text { memperbaiki CAR dan meningkatkan likuiditasnya } \\
\text { yang selanjutnya bank dapat memberikan kredit baru. } \\
\text { - Sekuritisasi asset akan memberikan dampak terhadap } \\
\text { perkembangan uang beredar (M2). Dampak yang } \\
\text { bersifat menambah uang beredar terutama terjadi } \\
\text { melalui proses penggandaan uang. Pinjaman dari } \\
\text { maupun pembelian asset oleh SPV (Spesial Purpose } \\
\text { Vehicle) berpotensi meningkatkan uang beredar } \\
\text { melalui mebaiknya likuiditas perbankan sehingga } \\
\text { bank dapat meningkatkan kredit yang diberikan. }\end{array}$ \\
\hline 2. & $\begin{array}{l}\text { Park, Jae-Ha et.al } \\
\text { (2008) } \\
\text { Developing the } \\
\text { Capital Market to } \\
\text { Widen and Diversity } \\
\text { SME Financing: The } \\
\text { Korean Experience }\end{array}$ & $\begin{array}{l}\text { - Kesulitan utama dalam meniadakan hambatan } \\
\text { pembiayaan di sektor UMKM (SME financing gap) } \\
\text { adalah asymmetric information. } \\
\text { - Melalui system sharing informasi, lembaga keuangan } \\
\text { dapat menyediakan pembiayaan kepada UMKM } \\
\text { secara efisien. }\end{array}$ \\
\hline 3. & $\begin{array}{lr}\text { Kimborough, } & \text { Robert } \\
\text { T-Summary } & \text { of } \\
\text { American } & \text { Law. } \\
\text { Lederman } & \text { Jass } \\
(1996) & \end{array}$ & $\begin{array}{l}\text { Alasan perusahaan memilih mencari dana melalui sekuritisasi } \\
\text { asset a.i: } \\
\text { - Biaya finansial yang sangat rendah. Dengan } \\
\text { menggunakan asset yang dimiliki, perusahaan dapat } \\
\text { melakukan penjualan efek dengan kualitas kredit yang } \\
\text { tinggi dibandingkan dengan nilai perusahaaan } \\
\text { tersebut. } \\
\text { - Penghematan modal. Apabila dikaitkan dengan } \\
\text { pembatasan hutang perusahaan khususnya bagi } \\
\text { lembaga keuangan, oleh karena ketentuan pasar } \\
\text { modal, maka transaksi dengan pola penjualan asset } \\
\text { (true sale) dalam system akuntansi dapat mengurangi } \\
\text { kebutuhan modal yang besar (higher cost equity). } \\
\text { - Strategi pendanaan yang sesuai. Dengan sekuritisasi } \\
\text { efek perusahaan dapat menawarkan pola , jangka } \\
\text { waktu dan harga dasar atas efek tersebut. }\end{array}$ \\
\hline
\end{tabular}




\begin{tabular}{|c|c|c|}
\hline & & $\begin{array}{l}\text { - Pendapatan. Apabila konsep sekuritisasi adalah } \\
\text { penjualan asset (true sale), penerbit atau penjual } \\
\text { diperbolehkan untuk mengetahui, sesuai prinsip } \\
\text { standard akuntansi (GAAP), keuntungan atau } \\
\text { kerugian penjualan asset tersebut, yang } \\
\text { diperhitungkan dengan nilai saat ini (present value) } \\
\text { dan ekspektasi nilai yang akan datang. }\end{array}$ \\
\hline 4. & $\begin{array}{l}\text { Norton, Joseph J, et } \\
\text { al.-International } \\
\text { Finance in the } \\
\text { 1990s. } \\
\text { Blackwell } \\
\text { Publisher,1993. }\end{array}$ & $\begin{array}{l}\text { Alasan investor melakukan investasi pada sekuritisasi asset: } \\
\text { - Sebagai alternative pendanaan jangka panjang 3-10 } \\
\text { tahun karena KIK EBA lebih menarik bagi investor } \\
\text { dibanding surat utang lain, seperti obligasi dan } \\
\text { promes, karena didukung dengan asset yang likuid } \\
\text { dan risiko yang relative kecil. } \\
\text { - Meski originator (penerbit) bangkrut, tagihannya tetap } \\
\text { ada. Ini berbeda dari pembeli obligasi atau promes, } \\
\text { yang akan kehilangan dananya apabila perusahaan } \\
\text { yang bersangkutan bangkrut. }\end{array}$ \\
\hline 5. & $\begin{array}{l}\text { Gan, Yingjin Hila } \\
\text { dan Christopher } \\
\text { Mayer-“Agency } \\
\text { Conflicts, Asset } \\
\text { Subtitution, and } \\
\text { Securitization" } \\
\text { National Bureau of } \\
\text { Economic Research, } \\
\text { Cambridge, 2006. }\end{array}$ & $\begin{array}{l}\text { Manfaat dan masalah potensial dalam sekuritisasi asset: } \\
\text { - } \quad \text { Manfaat dari ABS adalah pengembangan pasar untuk } \\
\text { sekuritas, peningkatan likuiditas, dan tranparansi. } \\
\text { - Sekuritisasi asset dapat menimbulkan moral hazard } \\
\text { dan konflik lembaga yang terkait dengan pemisahan } \\
\text { kepemilikan dan pengendalian asset dan konflik } \\
\text { kepentingan antara pemegang junior (junior tranche) } \\
\text { dan senior (senior tranche). }\end{array}$ \\
\hline 6. & $\begin{array}{l}\text { Masahiko Egami } \\
\text { dan Kaoru Hosono. } \\
\text { Journal "A Model } \\
\text { for Bank's Optimal } \\
\text { Asset Securitization } \\
\text { Program" } \\
\text { (KyotoUniversity- } \\
\text { Japan) }\end{array}$ & $\begin{array}{l}\text { Menjelaskan secara optimal bagaimana bank melakukan } \\
\text { sekuritisasi dengan memasukan ilmu stochastic asset return } \\
\text { dan leverage constraints. Dan menghitung seberapa banyak } \\
\text { keuntungan yang didapatkan program sekuritisasi asset. } \\
\text { Juga memasukan economic environment dan trend } \\
\text { sekuritisasi termasuk bubble ekonomi dan periode krisis. } \\
\text { Seperti ada } 4 \text { parameters dan hasil dari } 4 \text { kasus dari } \\
\text { sekuritisasi asset terdiri dari case normal, bubble, } \\
\text { deteriorating dan crisis. }\end{array}$ \\
\hline
\end{tabular}




\section{F. Kesimpulan dan Saran}

\section{Kesimpulan}

Sejak program sejuta rumah dicanangkan oleh Presiden Joko Widodo pada tanggal 29 April 2015. Pemerintah diwakili Kementerian Pekerjaan Umum-Perumahan Rakyat melalui Direktorat Penyediaan Perumahan dan Direktorat Pembiayaan Perumahan telah menginisiasi Pembangunan Program Sejuta Rumah. Bank BTN telah ditunjuk untuk menyalurkan kredit perumahan KPR bersubsidi dalam program sejuta rumah pemerintah bekerja sama dengan asosiasi-asosiasi Pengembang seperti REI (Real Estate Indonesia), APERSI (Asosiasi Pengembang Rumah Seluruh Indonesia), Apernas (Asosiasi Pengembang Rumah Sederhana Sehat Nasional) dimana untuk mendorong percepatan program sejuta rumah. Adapun kendala-kendala yang dihadapi adalah:

a. Backlog (kekurangan pasokan) perumahan menurut data BPS dan Bappenas sebesar 13.5 juta unit (Data tahun 2015).

b. Banyaknya regulasi perijinan yang harus dipenuhi oleh pengembang.

c. Lokasi perumahan yang kurang strategis disamping harga tanah yang mahal.

d. Peraturan daerah yang belum sejalan dengan peraturan diterbitkan oleh pemerintah pusat.

e. Harga rumah yang semakin mahal rata rata kenaikan $5 \%$ untuk rumah subsidi dan non subsidi $20 \%$ tergantung lokasinya.

f. Tingkat laju pertambahan penduduk rata rata pertahun $1,49 \%$.

g. Kredit perumahan - FLPP (dari Pemerintah) hanya mampu memasok rumah KPR Subsidi melalu KPR FLPP hanya 58.000 unit pertahun (jumlah nominal Rp 9 T).

h. Kendala pembiayaan KPR perumahan dari pemerintah melalui APBN.

Kendala terbesar adalah mengenai keterbatasan pembiayaan perumahan bersubsidi dari Pemerintah melalui APBN, dimana alokasi dari APBN hanya sebesar 9 triliun (thn 2015) yang hanya mampu membiayai kredit KPR sebanyak 58.000 unit rumah ke golongan MBR dan PNS yang berpenghasilan dengan gaji pokok Rp 4 juta. Merujuk skema perhitungan backlog perumahan sebesar 13.5 juta jika dikalikan dengan harga rumah bersubsidi jika dirata ratakan sekitar Rp 135 juta (Type 36) perunit, maka dana yang dibutuhkan adalah sebesar Rp 1.820 triliun. Jumlah yang sangat besar, untuk itu dibutuhkan suatu SPV (Spesial Purpose Vehicle) untuk dapat memaksimalkan dana dari pasar modal melalui sekuritisasi asset (EBA-SP) dimana untuk membiayai backlog perumahan yaitu melalui EBA-SP.

\section{Saran}

Kemampuan pendanaan Bank BTN bisa dilakukan melalui Sekuritisasi KPR, yakni menjual asset cicilan KPR yang dimiliki ( kredit yang high quality, kualitas lancar) melalui BTN sebagai originator kredit KPR dan yang bertindak sebagai penerbit efek EBA-SP adalah PT SMF yang akan melakukan sekuritisasi asset yang akan dijual kepada investor dalam bentuk surat efek. EBA-SP adalah merupakan suatu proses mentransformasi atau mengubah sesuatu yang bukan efek menjadi efek yang bersifat likuid sehingga mudah diperdagangkan dan dapat mendukung kredit perumahan bersubsidi yang dicanangkan oleh Pemerintah dengan harapan dapat menurunkan backlog perumahan. 


\section{G. Daftar Pustaka}

Bank BTN. “Annual Report Tahun 2009-2016”.

Bank BTN. "Perhitungan Bunga EBA-SP".

Bank BTN-SMF. "Kerjasama Bank BTN-SMF Lahirkan Sekuritisasi Terbesar Sepanjang Sejarah".

Bank Indonesia dan OJK. "Kinerja Perbankan Indonesia 2006-2016".

BAPPENAS \& BPS. “Data Backlog Perumahan”.

Bulletin BTN-REI 10 Mei 2016.

Detik Finance Rabu 5 April 2017.

Direktorat Jenderal Anggaran Kementerian Keuangan 2015. Peranan APBN Dalam Mengatasi Backlog Perumahan Bagi Masyarakat Berpenghasilan Rendah (MBR)".

Kementerian Pekerjaan Umum dan Perumahan Rakyat Republik Indonesia, PPDPP (Pusat Pengelolaan Dana Pembiayaan Perumahan)."Konsep Backlog Perumahan".

Kontan Rabu, 22 Maret 2017.

Masahiko Egami, Kaoru Hosono. (Graduate School of Economics Kyoto UniversityJapan), Journal "A Model for Bank's Optimal Asset Securitization Program".

Nardi Sunardi (2017) Determinan Kebijakan Utang Serta Implikasinya terhadap Kinerja Perusahaan (Perusahaan yang tergabung dalam indeks LQ.45 yang terdaftar di Bursa Efek Indonesia Tahun 2011- 2015) Jurnal Sekuritas, Vol. 1, No.1 I September 2017 Universitas Pamulang.

Nardi Sunardi, Aceng Abdul Hamid, Lativa, Abdul Kadim, Natanael Tulus (2018) Determinant Of Cost Efficiency And It's Implications For Companies Performance Incorporated In The Lq.45 Index Listing In Idx For The Period of 2011-2016, International Journal of Applied Business and Economic Research,..Volume 16, Number 1, 2018, ISSN : 0972-7302

Paripurna P. Sugarda." Sekuritisasi Aset Dalam Kontrak Investasi Kolektif Beragun Aset di Indonesia".

Sarana Multigriya Finansial (SMF). "Efek Beragun Aset Berbentuk Surat Partisipasi”.

Wijoyo Santoso, Shinta R.I Soekro, Darmansyah, Hilde D. Sihaloho. "Pemanfaatan Sekuritisasi Aset Dalam Mendorong Sektor Riil: Alternatif Pembiayaan UMKM". 